Зора ЈАЧОВА

УДК:159.937.24:159.946.3

Иидија РИСТОВСКА

Ђудмил СПАСОВ

Изворен научен труд

\title{
ТРАНЗИЦИИТЕ НА ФОРМАНТИТЕ КАКО АКУСТИЧНИ ЗНАЦИ ЗА МЕСТОТО НА АРТИКУ ИАЦИЈА ВО ПЕРЦЕПЦИЈАТА НА ГОВОРОТ
}

\section{Кратка содржина}

Транзициите на формантите ја рефлектираат вкупната промена на формата на вокалниот тракт во текот на продукцијата на говорот. Целтана студијата беше да се анализира транзицичата на F1 и на F2 на македонските вокали во контекст на консонанти. Студијата вклучува 12 родени говорители на македонски јазик (средна возраст 42,7士11,9 години).

Вокалот /о/ во контекстот на дентално-алвеоларен плозив /до/ имаше десцендентна транзиција на F2 во траене од 38 ms и размер на транзицијата $772 \mathrm{~Hz}$, а во контекстот на веларен плозив /zo/ десцендентна транзиција на F2 во траене od 25 ms и размер $85 \mathrm{~Hz}$. Вокалот /al во контекстот на алвеоларен фрикатив /ша/ имаше десцендентна транзиција на F2 во траене од 25 ms и размер $324 \mathrm{~Hz}$, а во контекстот на лабијален фрикатив / ба/ имаше асиендентна транзиција на F2 во траетье од $38 \mathrm{~ms}$ и размер $214 \mathrm{~Hz}$. Вокалот ly/ во контекстот на палатален фрикатив /jy/ имаше десиендентна транзиција на F2 во траене од 48 ms и размер $1084 \mathrm{~Hz}$. Покусот на F2 за дентално-алвеоларен консонант беше $1900 \mathrm{~Hz}$, за веларен $2100 \mathrm{~Hz}$, за алвеоларен $1700 \mathrm{~Hz}$, за лабијален $1200 \mathrm{~Hz}$ и за палатален консонант беше $2600 \mathrm{~Hz}$.

Аокусот на F2 е највисок за палаталните консонанти, а најнизок за лабијалните консонанти. Транзицијата на F2 е акустичен знак за местото на артикулациија.

Клучни зборови: КОАРТИКУЛАЦИЈА, ТРАНЗИЦИЈА НА ФОРМАНТ, АРТИКУЯАЦИЈА, ПЕРЦЕПЦИЈА НА ГОВОР

\section{Вовед}

Коартикулацијата генерално се дефинира како влијание на еден фонетски сегмент врз друг (Marchal, 2009). Таа е преклопување помеѓу артикудациите на соседните фонеми. Артикулаторите постојано се движат додека зборуваме, така што формата на вокалниот тракт за одредена фонема е под влијание на формите за фонемата што иे претходи и што ја следи (Goldstein, 2010). Генерално, коартикулаторните ефекти може да се поделат во две групи: дево кон десно иди преносни ефекти, кај кои својствата на сегментот се пренесуваат за да вдијаат на својствата на следниот сегмент и 
десно кон лево или антиципаторни ефекти, кај кои својствата на сегментот влијаат на својствата на претходните сегменти (Tatham и Morton, 2006).

Мерењето на формантите е еден од елементите на акустичната анализа на вокалите. Првите два форманти се најважни за идентификување на вокалот (Raina, Chakraborty и Velankar, 2014). Формантот е концентрација на акустична енергија околу одредена фреквенција на звучниот бран и кореспондира со резонанцијата на вокалниот тракт. Формантите може да се видат многу јасно на широкопојасен спектрограм каде што се прикажуваат како темни појаси. Тие се означени како F1, F2, F3, F4 итн. почнувајќи со најниската фреквенција (Gunasekar, и cop., 2017). F1 примарно е поврзан со висината на јазикот, така што високите вокади имаат ниска фреквенција на F1, а ниските вокали имаат висока фреквенција на F1. F2 најмногу се поврзува со поместувањето на јазикот кон напред, така што задните вокали имаат ниска фреквенција на F2, а предните вокали имаат висока фреквенција на F2 (Ludlow, Kent и Gray, 2019).

Движењата на вокалниот тракт продуцираат транзиции на фреквенциите на формантите. Транзициите на формантите ја рефлектираат вкупната промена на формата на вокалниот тракт во текот на продукцијата на говорот (Story и Bunton, 2010). Централниот дел на вокалот каде што фреквенцијата е релативно стабилна се нарекува стабилна состојба (Maltby, 2002). Транзицијата на формантот се дефинира како промена од $20 \mathrm{~Hz}$ или повеќе во интервал од $20 \mathrm{~ms}$. Алтернативно, стабилната состојба на вокалот се претпоставува дека постои ако стапката на промена во формантот е помала од $20 \mathrm{~Hz}$ во интервал од 20 ms (Blomgren и Robb, 1998). Голем број студии ја демонстрирале важноста на транзициите на формантите на вокалот што следи за идентификација на местото на артикулација на консонантите (Baken и Orlikoff, 2000; Kishon-Rabin, Dayan и Michaeli, 2003; Kerdpol, 2012).

Важен концепт во опишувањето на транзициите на формантите е локусот на формантот. Локусот претставува видлива точка на потекло на формантот за секое место на артикулација на консонантите (Ladefoged и Johnson, 2011). Локусот на F2 е од особен интерес бидејќи тој помага да се дефинираат транзициите на F2 што игра важна улога во фонетското одлучување и интелигибидноста на говорот. Аокусот е претпоставена фреквенција за одредено место на артикулација. Времетраењето на транзицијата на формантот е интервалот во кој се јавува значителен дел од транзицијата на формантот. Транзицијата може да има раздични форми, како десцендентна, речиси рамна или асцендентна (Ludlow, Kent и Gray, 2019). Генерално, транзицијата на F2 со нискофреквентен локус укажува на перцепција на лабијален глас, таа со повисок локус укажува на перцепција на алвеоларен глас и варијабилен, локус зависен од вокалот, укажува на палатален или на веларен глас (Raphael, Borden и Harris, 2011).

Целта на студијата беше да се анализира транзицијата на F1 и на F2 на македонските вокали кои следат по консонанти со раздично место на 
артикулација, како и да се компарираат фреквенциите на формантите во контекст на консонанти со фреквенциите на формантите на вокадите како изолирани фонеми.

\section{Методи}

Студијата вкдучува 12 родени говорители на македонски јазик, шест мажи и шест жени, на возраст од 26 до 64 години (средна возраст 42,7士11,9 години). Тие ги изговорија македонските вокали и следните едносложни и двосложни зборови: дожд (dozd), шал (fal), фарма (farma), готви (gotvi), и jyz (jug). Зборовите беа снимени со користење на микрофонот Sennheiser e 840 (Sennheiser electronic, Германија). Акустичната анализа на WAV-фајловите е изведена во компјутерската програма Praat, Верзија 6.0.43 (Boersma и Weenink, 2018). Ги поставивме параметрите за анализа Максимална фреквенција на форманти (Hz) и Преглед на опсег $(\mathrm{Hz})$ на спектрограмот: 5000 $\mathrm{Hz}$ за мажите и $5500 \mathrm{~Hz}$ за жените. Ги одредивме основната фреквенција (Fo) и F1 до F5 и ги анализиравме транзициите на F1 и на F2 во контекст на консонанти. Сегментацијата на вокалите во зборовите е изведена со мануелен пристап.

\section{Резултати}

Анализирани се транзициите на формантите во консонант-вокал секвенци од реални зборови. Во анализата се вклучени консонанти со различно место на артикулација. Ги користевме симболите од Меѓународната фонетска азбука (МФА) за македонските гласови. Осцилограмот и спектрограмот на зборот [дожд/dozd] изговорен од женски говорител се прикажани на слика 1. Анализиран е вокалот /о/ (о) во контекстот на консонант /до/ (do). Македонскиот консонант /д/ (d) е дентално-алвеоларен плозив. 


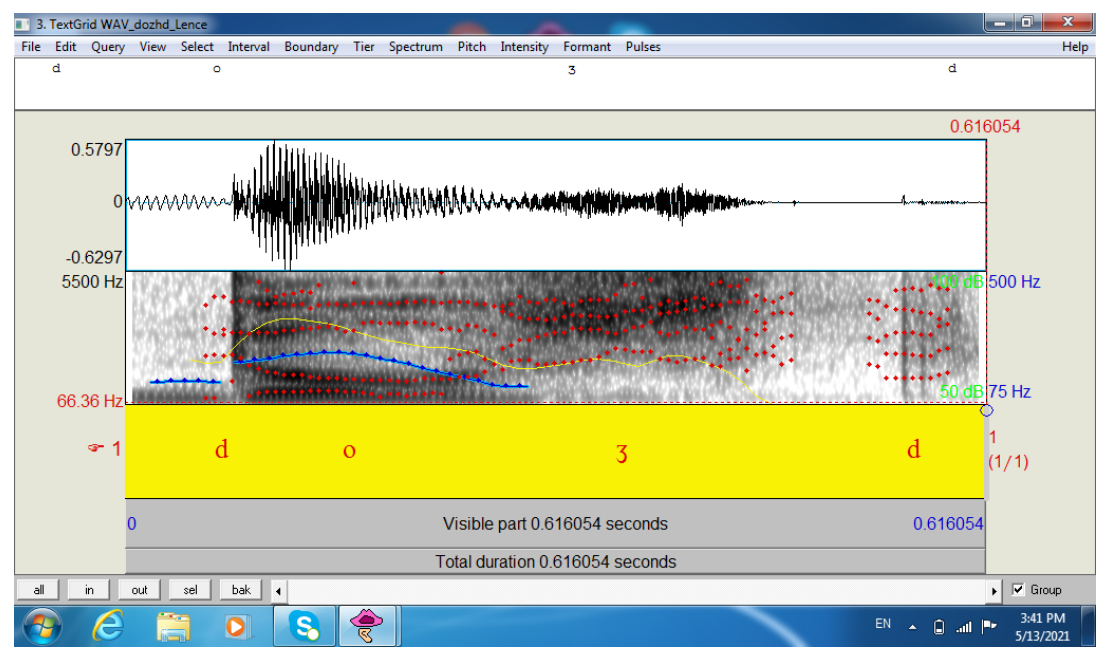

Слика 1. Осцуилограм и спектрограм на зборот [дожд/дозd]

Постоеше асцендентна транзиција на F1 и десцендентна транзиција на F2 на вокалот /o/ (о). Вокалот беше сегментиран во траење од 175 ms. Времетраењето на транзицијата на F1 беше $25 \mathrm{~ms}$, а размерот на транзицијата беше $234 \mathrm{~Hz}$, од 218 до $452 \mathrm{~Hz}$. Времетраењето на транзицијата на F2 беше 38 ms. Во тој период, фреквенцијата на формантот опаѓа за 772 Hz, од 1921 до 1149 Hz. Локусот на F2 за дентално-алвеоларниот консонант најверојатно е околу $1900 \mathrm{~Hz}$. Ги прикажавме формантите на вокалот /о/ (о) во зборот [дожд/dozd] со забележливо поголем размер на транзицијата на F2 (слика 2).

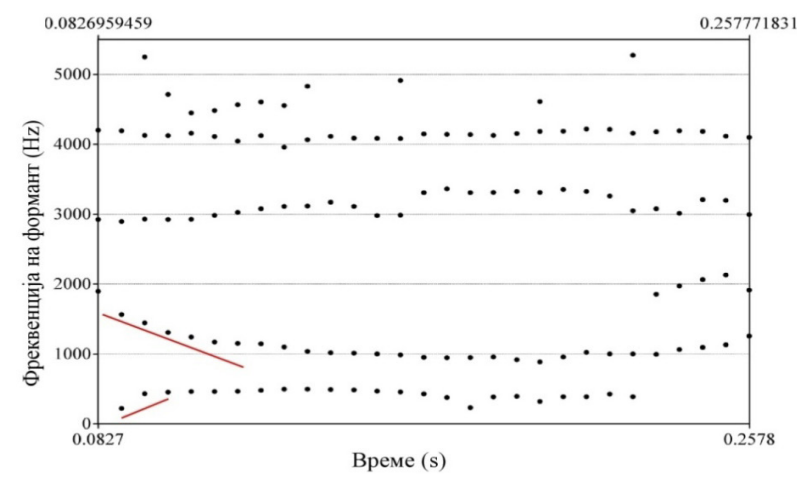

Слика 2. Форманти на вокалот /o/ (о) во зборот [дожд/dозd] 
Во табела 1 ги прикажавме Fо и фреквенциите на формантите на вокалот /о/ (о) во контекстот на плозив /до/ (do) и изолираниот вокал /o/ (o) кај женските говорители. F2 на вокалот /о/ (о) во контекстот на плозив /до/ (do) беше 1114 Hz, а F2 на изолираниот вокал /о/ (о) беше $1097 \mathrm{~Hz}$.

Table 1.

Ғо и форманти на вокалот /о/ (о) (во Нz)

\begin{tabular}{|l|l|l|l|}
\hline $\begin{array}{l}\text { Fo / Фор- } \\
\text { манти }\end{array}$ & $\begin{array}{l}\text { Вокал /о/ во контек- } \\
\text { стот /до/ (женски } \\
\text { говорител) }\end{array}$ & $\begin{array}{l}\text { Изолиран вокал } \\
\text { /о/ } \\
\text { (женски говори- } \\
\text { тел) }\end{array}$ & $\begin{array}{l}\text { Изолиран вокал/о/ } \\
\text { (средна вред- } \\
\text { ност } \pm \text { Сд) }\end{array}$ \\
\hline Fo & 222 & 210 & $209 \pm 18$ \\
\hline F1 & 454 & 718 & $558 \pm 76,5$ \\
\hline F2 & 1114 & 1097 & $1205 \pm 166,1$ \\
\hline F3 & 3230 & 3158 & $3133 \pm 95,2$ \\
\hline F4 & 4125 & 3699 & $3937 \pm 185,8$ \\
\hline F5 & 4670 & 4448 & $4848 \pm 278,4$ \\
\hline
\end{tabular}

Го анализиравме зборот [шал//al] изговорен од машки говорител. Осцилограмот и спектрограмот на зборот [шал/Jal] се прикажани на слика 3. Анализиран е вокалот /a/ (а) во контекстот на алвеоларен фрикатив /ша/ ( (a). Постоеше асцендентна транзиција на F1 и десцендентна транзиција на F2 на вокалот /a/ (a). Времетраењето на зборот [шал/fal] беше $422 \mathrm{~ms}$, а сегментираниот вокал /a/ (a) траеше 127 ms. Времетраењето на транзицијата на F1 беше 37 ms. Во тој период F1 порасна за 299 Hz, од 529 до 858 Hz.

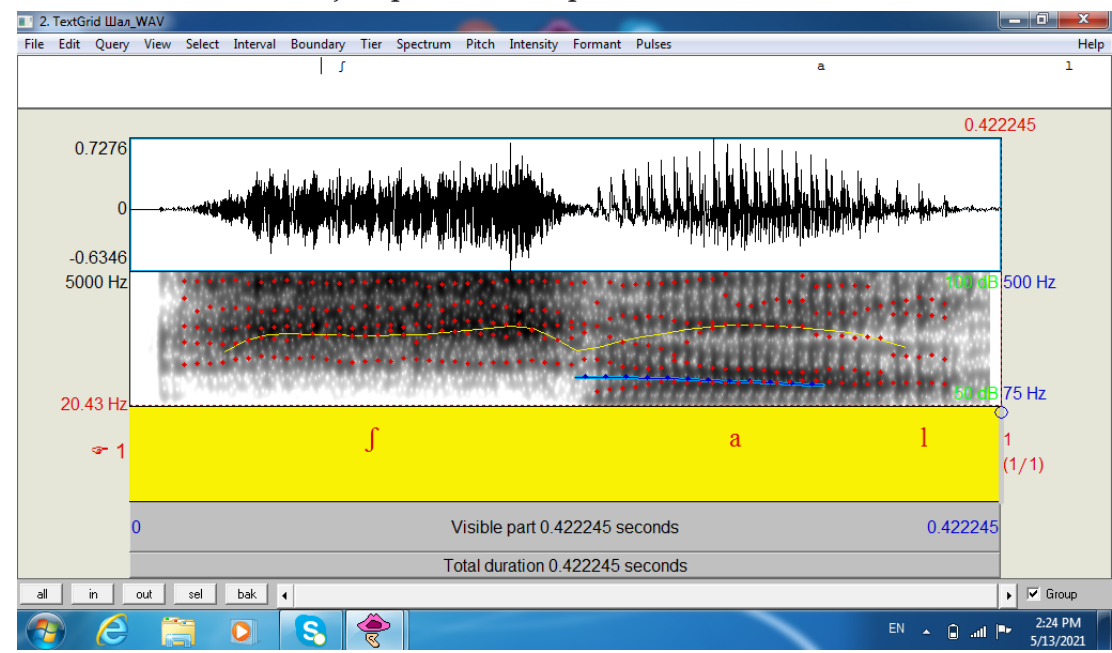

Слика 3. Осициограм и спектрограм на зборот [maл//al] 
Времетраењето на транзицијата на F2 беше 25 ms и фреквенцијата на формантот опадна за $324 \mathrm{~Hz}$, од 1678 до $1354 \mathrm{~Hz}$. Локусот на F2 за алвеоларниот консонант најверојатно е околу $1700 \mathrm{~Hz}$. На слика 4 ги прикажавме формантите F1 до F5 на вокалот /a/ (а) во зборот [шал/Јal]. Постои раздична форма на транзицијата помеѓу првите два форманти и кратка „стабилна состојба“ на F2.

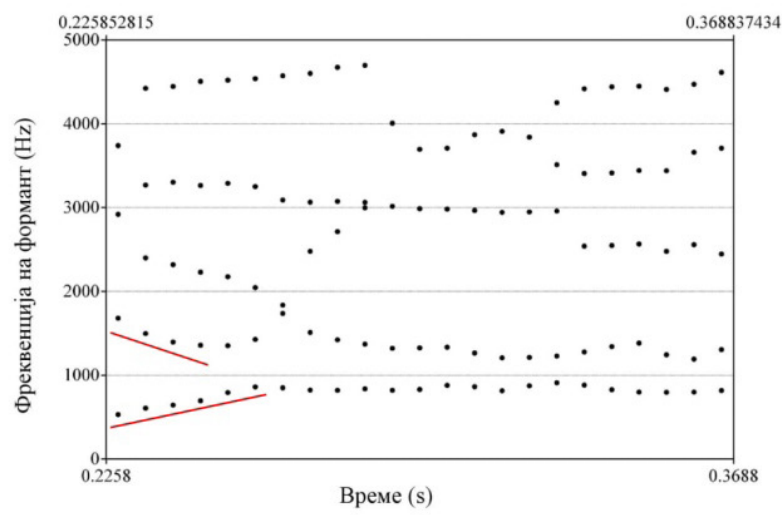

Слика 4. Форманти на вокалот /a/ (а) во зборот [uал/fal]

Ги прикажавме Fo и фреквенциите на формантите на вокалот /a/ (a) (табела 2). F2 на вокалот /a/ (а) во контекстот на фрикатив /ша/ ( $а$ ) беше $1425 \mathrm{~Hz}$, а F2 на изолираниот вокал /a/ (а) беше $1323 \mathrm{~Hz}$.

Табела 2.

Ғо и форманти на вокалот /a/ (a) (во Нz)

\begin{tabular}{|l|l|l|l|}
\hline $\begin{array}{l}\text { Fo / Фор- } \\
\text { манти }\end{array}$ & $\begin{array}{l}\text { Вокал /a/ во контек- } \\
\text { стот /ша/ (машки } \\
\text { говорител) }\end{array}$ & $\begin{array}{l}\text { Изодиран вокал /a/ } \\
\text { (машки говори- } \\
\text { тел) }\end{array}$ & $\begin{array}{l}\text { Изодиран вокал /a/ } \\
\text { (средна вред- } \\
\text { ност } \pm \text { Сд) }\end{array}$ \\
\hline Fo & 166 & 145 & $115 \pm 14,7$ \\
\hline F1 & 831 & 853 & $733 \pm 78$ \\
\hline F2 & 1425 & 1323 & $1161 \pm 81,1$ \\
\hline F3 & 2817 & 2574 & $2667 \pm 118,1$ \\
\hline F4 & 3508 & 3278 & $3413 \pm 173,1$ \\
\hline F5 & 4657 & 4304 & $4410 \pm 328$ \\
\hline
\end{tabular}

Транзициите на формантите на вокалот /a/ (а) се анализирани во контекстот на лабијален фрикатив /фа/ (fa) во зборот [фарма/farma] изговорен од женски говорител. Осцилограмот и спектрограмот на зборот 
[фарма/farma] се прикажани на слика 5. Постоеше асцендентна транзиција на F1 и на F2.

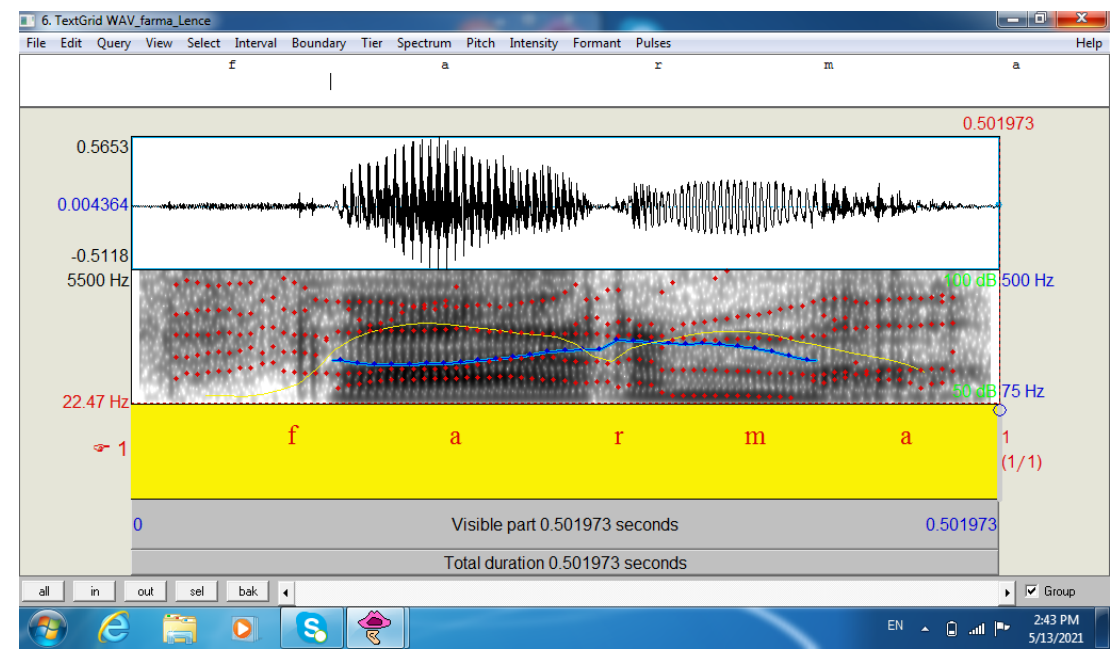

Слика 5. Осициограм и спектрограм на зборот [фарма/farma]

Зборот [фарма/farma] траеше $502 \mathrm{~ms}$, а првиот вокаи /a/ (a) траеше $149 \mathrm{~ms}$. Времетраењето на транзицијата на првиот формант беше $29 \mathrm{~ms}$. Во тој период F1 порасна за 296 Hz, од 644 до 940 Hz. Времетраењето на транзицијата на F2 беше $38 \mathrm{~ms}$ и фреквенцијата на формантот порасна за $214 \mathrm{~Hz}$, од 1169 до $1383 \mathrm{~Hz}$. Локусот на F2 за лабијалниот консонант најверојатно е околу $1200 \mathrm{~Hz}$. На слика 6 ги прикажавме формантите на вокалот /a/ (а) во зборот [фарма/farma].

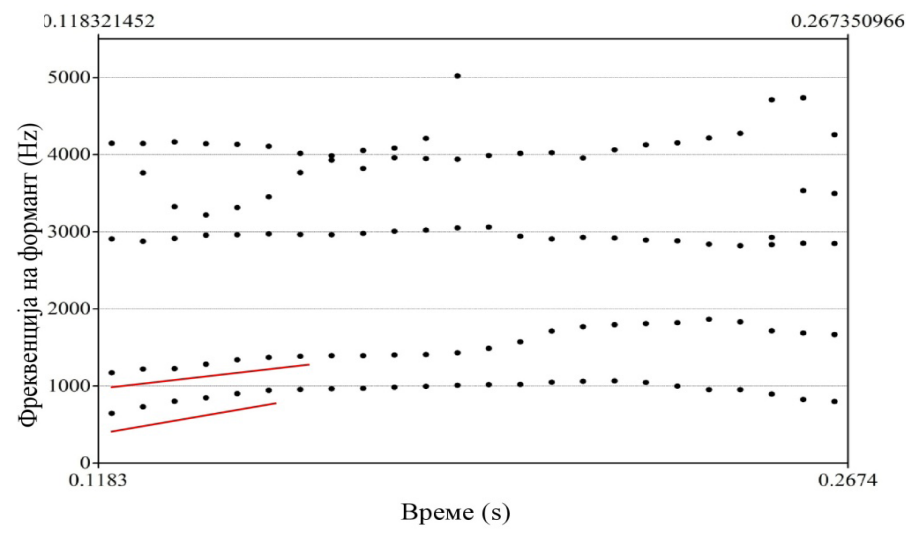

Слика 6. Форманти на првиот вокал /a/ (а) во зборот [фарма/fатта] 
Во табела 3 ги прикажавме Fо и фреквенциите на формантите на вокалот /a/ (а) во контекстот на фрикатив /фа/ (fa) и изолираниот вокал /a/ (a). F2 на вокалот /a/ (а) во контекстот на фрикатив /фа/ (fa) е $1557 \mathrm{~Hz}$, a F2 на изолираниот вокал /a/ (a) е $1448 \mathrm{~Hz}$.

\section{Табела 3.}

Ғо и форманти на вокалот /a/ (a) (во Hz)

\begin{tabular}{|l|l|l|l|}
\hline $\begin{array}{l}\text { Fo / Фор- } \\
\text { манти }\end{array}$ & $\begin{array}{l}\text { Вокал /а/ во контек- } \\
\text { стот /фа/ (женски } \\
\text { говорител) }\end{array}$ & $\begin{array}{l}\text { Изолиран вокал /a/ } \\
\text { (женски говори- } \\
\text { тел) }\end{array}$ & $\begin{array}{l}\text { Изолиран вокал /a/ } \\
\text { (средна вред- } \\
\text { ност } \pm \text { СД) }\end{array}$ \\
\hline Fo & 199 & 198 & $204 \pm 31$ \\
\hline F1 & 994 & 1035 & $869 \pm 129,6$ \\
\hline F2 & 1557 & 1448 & $1467 \pm 162,9$ \\
\hline F3 & 2952 & 2905 & $2896 \pm 187,1$ \\
\hline F4 & 3915 & 3639 & $3866 \pm 247,4$ \\
\hline F5 & 4198 & 4307 & $4842 \pm 316,3$ \\
\hline
\end{tabular}

Ги анализиравме транзициите на формантите во зборот [готви/ gotvi]. Осцилограмот и спектрограмот на зборот [готви /gotvi] изговорен од машки говорител се прикажани на слика 7.

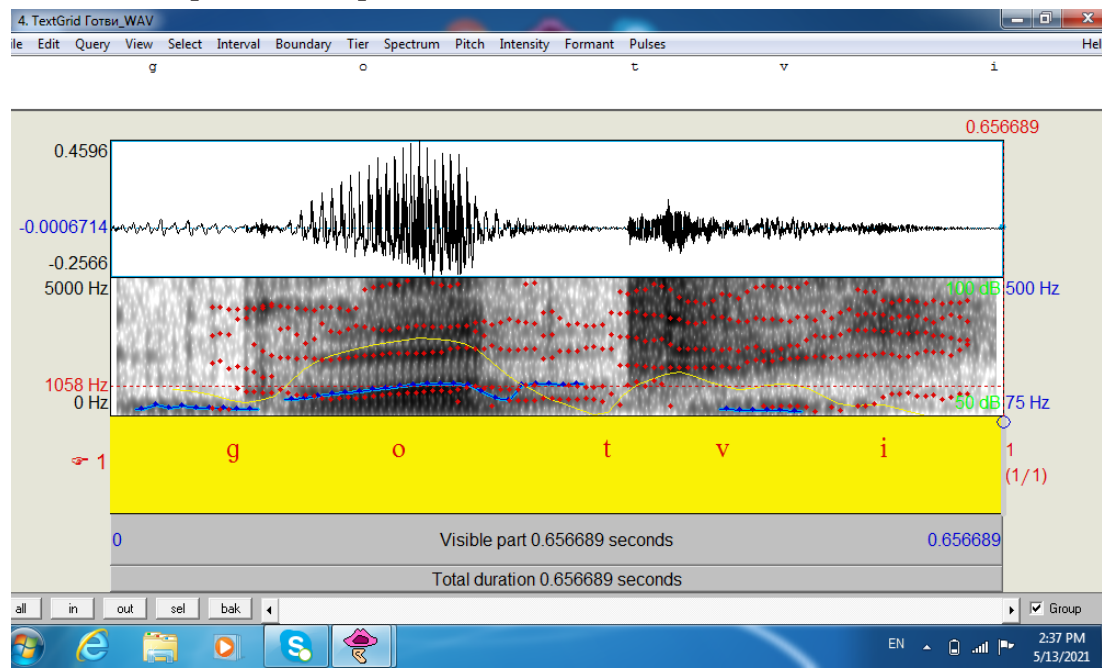

Слика 7. Осичилограм и спектрограм на зборот [zоmви/gotvi]

Анализиран е вокалот /о/ (о) во контекстот на веларен плозив /го/ (go). Зборот [готви/gotvi] траеше 657 ms, а вокалот /o/ (о) траеше 135 ms. Времетраењето на транзицијата на F1 беше 26 ms и фреквенцијата на фор- 
мантот опадна за $131 \mathrm{~Hz}$, од 692 до $561 \mathrm{~Hz}$. Времетраењето на транзицијата на F2 беше 25 ms и фреквенцијата на формантот опадна за 85 Hz, од 2056 до $1971 \mathrm{~Hz}$. Локусот на F2 за веларниот консонант најверојатно е околу 2100 Hz. На слика 8 ги прикажавме формантите на вокалот /o/ (о).

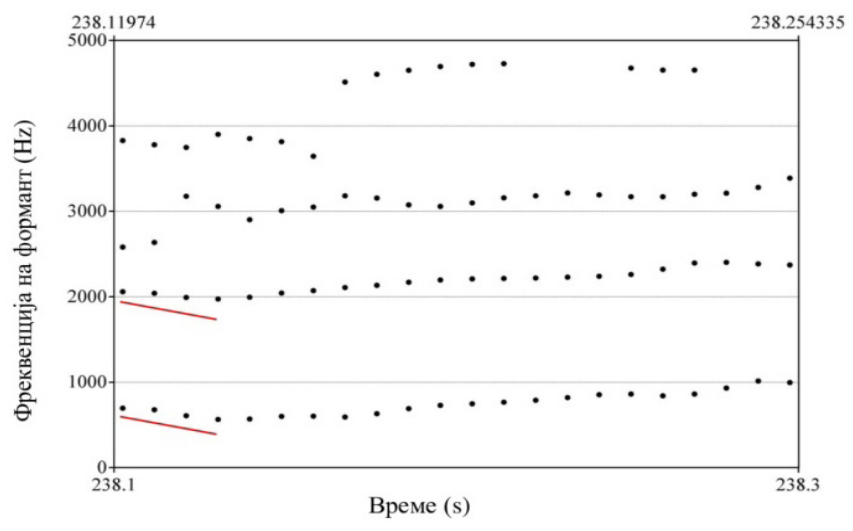

Сдика 8. Форманти на вокалот /o/ (о) во зборот [zomви/gotvi]

Во табела 4 ги прикажавме Fо и фреквенциите на формантите на вокалот /о/ (о) во контекстот на плозив /го/ (gо), изолираниот вокал /о/ (о) кај машкиот говорител што го изговори зборот [готви/gotvi] и средната вредност на Fo и фреквенциите на формантите кај машките говорители. F2 на вокалот /o/ (о) во контекстот на плозив /го/ (go) беше 2040 Hz. F2 на изолираниот вокал /о/ (о) беше $1506 \mathrm{~Hz}$ во траење на вокалот од $284 \mathrm{~ms}$.

Табела 4.

Го и форманти на вокалот /о/ (о) (во Нz)

\begin{tabular}{|l|l|l|l|}
\hline $\begin{array}{l}\text { Fo / } \\
\text { Formants }\end{array}$ & $\begin{array}{l}\text { Вокал/o/ во кон- } \\
\text { текстот/го/ (машки } \\
\text { говорител) }\end{array}$ & Изодиран вокал /o/ & Изолиран вокал/o/ \\
(машки говорител) & $\begin{array}{l}\text { (средна вред- } \\
\text { ност } \pm \text { Сд) }\end{array}$ \\
\hline Fo & 127 & 146 & $123 \pm 13,8$ \\
\hline F1 & 688 & 662 & $528 \pm 88,9$ \\
\hline F2 & 2040 & 1506 & $1087 \pm 274,4$ \\
\hline F3 & 3002 & 2822 & $2697 \pm 212,1$ \\
\hline F4 & 4098 & 3779 & $3598 \pm 122,2$ \\
\hline F5 & 4651 & 4049 & $4457 \pm 207,6$ \\
\hline
\end{tabular}

Вокалот /y/ (u) беше анализиран во контекстот на палатален фрикатив /jy/ (ju). Зборот [jyг/jug] беше изговорен од женски говорител. Осцииограмот и спектрограмот на зборот [jyг/jug] се прикажани на слика 9. 
Постоеше асцендентна транзиција на F1 и десцендентна транзиција на F2 на вокалот /y/ (u). Времетраењето на зборот [jyr/jug] беше $416 \mathrm{~ms}$, а времетраењето на вокалот /y/ (u) беше $125 \mathrm{~ms}$.

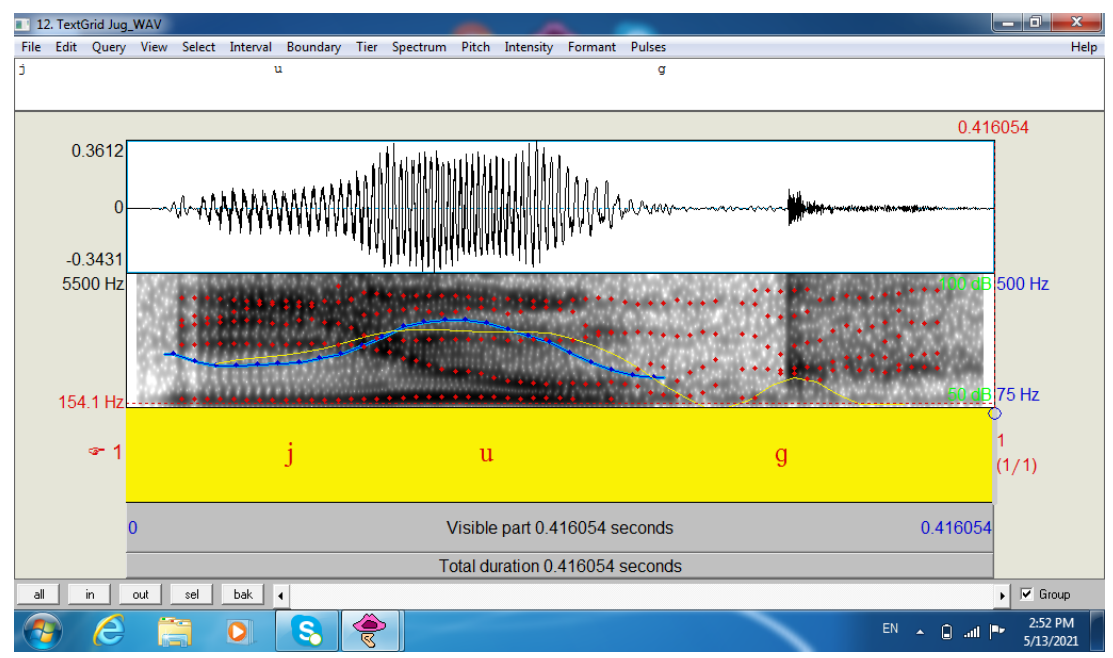

Слика 9. Осичилограм и спектрограм на зборот [jyz/jug]

Времетраењето на транзицијата на F1 беше $27 \mathrm{~ms}$ и фреквенцијата на формантот порасна за $63 \mathrm{~Hz}$ од 283 до $346 \mathrm{~Hz}$. Времетраењето на транзицијата на F2 беше $48 \mathrm{~ms}$ и фреквенцијата на формантот опадна за 1084 Hz, од 2537 до 1453 Hz. Локусот на F2 за палатален консонант најверојатно е околу $2600 \mathrm{~Hz}$.

На слика 10 ги прикажавме формантите на вокалот /y/ (u). Се забележува поголемиот размер на транзицијата на F2 во споредба со размерот на транзицијата на F1.

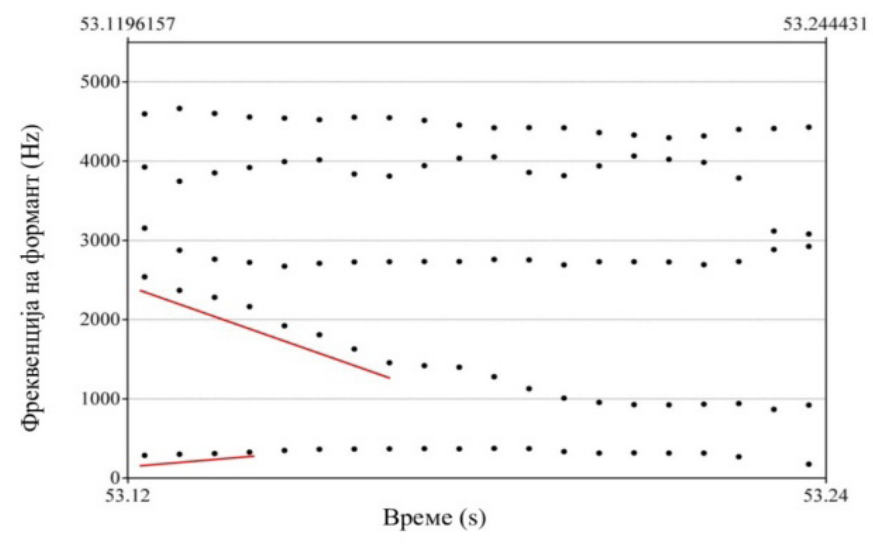

Слика 10. Форманти на вокалот /y/ (u) во зборот [jyzljug] 
Во табела 5 ги прикажавме Fo и фреквенциите на формантот на вокалот /y/ (u) во контекстот на фрикатив /jy/ (ju) и изолираниот воках /y/ (u). Вториот формант на вокалот /y/ (u) во контекстот на фрикатив /jy/ (ju) беше $1542 \mathrm{~Hz}$ во траење на вокалот од $125 \mathrm{~ms}$.

\section{Табела 5.}

Ғо и форманти на вокалот /y/ (и) (во Нz)

\begin{tabular}{|c|c|c|c|}
\hline $\begin{array}{l}\text { Fo / Фор- } \\
\text { манти }\end{array}$ & $\begin{array}{l}\text { Вокал /у/ во кон- } \\
\text { текстот /ју/ (жен- } \\
\text { ски говорител) }\end{array}$ & $\begin{array}{l}\text { Изолиран вокал /у/ } \\
\text { (женски говоритед) }\end{array}$ & $\begin{array}{l}\text { Изодиран вокал /у/ } \\
\text { (средна вред- } \\
\text { ност } \pm \text { СД) }\end{array}$ \\
\hline Fo & 258 & 238 & $255 \pm 22,8$ \\
\hline F1 & 352 & 386 & $416 \pm 52$ \\
\hline F2 & 1542 & 1320 & $1395 \pm 181,3$ \\
\hline F3 & 2781 & 3093 & $3129 \pm 235,8$ \\
\hline F4 & 3903 & 3992 & $4182 \pm 202,8$ \\
\hline F5 & 4469 & 4286 & $4821 \pm 253,1$ \\
\hline
\end{tabular}

(u) беше $1320 \mathrm{~Hz}$ во траење на вокалот од $249 \mathrm{~ms}$. Средната вредност на фреквенцијата на вториот формант кај сите женски говорители беше $1395 \pm 181,3 \mathrm{~Hz}$.

\section{Дискусија}

Ја анализиравме транзицијата на првиот и на вториот формант во контекст на консонанти во реални зборови. Според местото на артикулација, македонските консонанти се делат на: лабијални, дентално-алвеоларни, алвеоларни, палатални и веларни (Бојковска, и сор., 2008). Акустичните знаци за перцепција на говорните сегменти може да се поделат на знаци кои се важни за перцепција на начинот на артикулација, местото на артикулација и раздики во гласност. Акустични знаци за местото на артикулација се: формантниот простор, фреквенција на шумната компонента на консонантот и транзивијата на F2 (Raphael, Borden и Harris, 2011).

Акустичната анализа на говорните примероци е изведена во компјутерската програма Praat. Praat е софтвер за анализирање, синтетизирање и манипулирање со говор. Иако не е систем за синтеза на говор, со Praat може да се генерираат раздични звуци (Boersma и Weenink, 2001).

Ги анализиравме осцилограмите и спектрограмите на едносложните и на двосложните зборови. Спектрограмот е спектро-темпорална претстава на звукот. Хоризонталната насока на спектрограмот го претставува времето, а вертикалната насока ја претставува фреквенцијата (Proverbio, и cop., 2016). Нивото на затемнување на спектрограмот ја покажува амплитудата, така што темниот дел покажува присуство на сигнификантна енергија на таа фреквенција во тоа време (Taylor, 2009). 
За да се анализира транзицијата на формантите извршивме мануелна сегментација на вокалите. Мануелната сегментацијата на говорот се темели на слушање и визуелна процена со цел да се одредат бараните граници (Al-Manie, Alkanhal и Al-Ghamdi, 2010). Границите на вокалот се однесуваат на почетната и на крајната точка на вокалот. Крајната точка на вокалот се маркира како место на кое енергијата на вториот формант нагло опаѓa (Yadav и Rao, 2013).

При анализа на вокалот /о/ (о) во контекстот на дентално-алвеоларен плозив /до/ (do), утврдена е асцендентна транзиција на F1 и десцендентна транзиција на F2. Постоеше високофреквентен локус на F2, најверојатно околу $1900 \mathrm{~Hz}$. Вториот формант на вокалот /о/ (о) во контекст на консонант беше повисок од F2 на изолираниот вокал /o/ (о). Транзициите на формантите се детерминирани од движењата на јазикот и мандибулата затоа што овие структури се поместени кон вокалот од конфигурациите што тие мора да ги претпостават за да ја формираат оклузијата на плозивот (Stevens, 2000).

Ја анализиравме транзицијата на формантите на вокалот /a/ (а) во контекстот на алвеоларен фрикатив /ша/ ( (a). Артикулациите на фрикативите се резултат на два артикулатори кои се во тесна апроксимација еден со друг. Тоа е степен на стриктура при што артикулаторите се приближени така што воздухот може да помине помеѓу нив, но бидејќ́ процепот помеѓу нив е мал, воздушната струја станува турбулентна и креира фрикациски шум (Ogden, 2009). Постоеше асцендентна транзиција на F1 и десцендентна транзиција на F2. Локусот на F2 locus беше околу $1700 \mathrm{~Hz}$. Вториот формант на вокалот /a/ (а) во контекстот на фрикатив /ша/ ( (a) беше повисок од F2 на вокалот /a/ (а) изговорен како изолиран глас. Во англискиот јазик, транзиција на F2 со високофреквентен локус укажува на перцепција на алвеоларен глас (Raphael, Borden и Harris, 2011). Според Ladefoged и Johnson (2011) локусот на F2 за алвеоларните гласови е околу 1700-1800 Hz.

Во анализата на вокалот /a/ (а) во контекстот на лабијален плозив / фa/ (fa) најдовме асцендентна транзиција и на F1 и на F2. Вториот формант на вокалот /a/ (a) во контекстот на плозив /фа/ (fa) е повисок од F2 на вокалот /a/ (а) изговорен како изолиран глас. Докусот на F2 е најверојатно околу $1200 \mathrm{~Hz}$. Докусот за лабијален консонант е понизок во споредба со локусот на F2 за дентално-алвеоларен и алвеоларен консонант. Генерално, транзицијата на F2 со нискофреквентен локус укажува на перцепција на лабијален глас (Raphael, Borden и Harris, 2011). Според Ladefoged и Johnson (2011) локусот и на вториот и на третиот формант во контекст на билабијалните гласови се компаративно ниски.

Анализата на вокалот /о/ (о) во контекстот на веларен плозив /го/ (go) покажа десцендентна транзиција на F1 и на F2. Постоеше високофреквентен локус на F2 за веларниот консонант околу 2100 Hz. F2 на вокалот /о/ (о) во контекстот на фрикатив /го/ (go) е повисок од F2 на вокалот /o/ (о) изго- 
ворен како изолиран глас. Во ангдискиот јазик постои висок докус на F2 во контекст на веларните плозиви (Ladefoged и Johnson, 2011).

Ги анализиравме транзициите на формантите на вокалот /y/ (u) во контекстот на палатален фрикатив /jy/ (ju). Постоеше асцендентна транзиција на F1 и десцендентна транзиција на F2 со голем размер на транзицијата. Одредивме високофреквентен локус на F2 за палаталниот консонант околу $2600 \mathrm{~Hz}$. Во англискиот јазик, транзиција на F2 со варијабилен, иокус зависен од вокалот укажува на перцепција на палатален или на веларен глас (Raphael, Borden и Harris, 2011). Вториот формант на вокалот /y/ (u) во контекстот на фрикатив /jy/ (ju) е повисок од F2 на вокалот /y/ (u) изговорен како изолиран глас. Големиот размер на транзицијата на F2 може да се објасни со акустичната структура на гласот /j/ (j). Во однос на неговите артикулациски и акустични карактеристики гласот е сличен на вокалот /и/ (i) (Ристовска, и сор., 2018).

Времетраењето на транзицијата на вториот формант во контекст на плозив во нашата студија беше 25 и $38 \mathrm{~ms}$, а во контекст на фрикатив беше 25, 38 и $48 \mathrm{~ms}$. За англиските плозиви, времетраењето на транзицијата е во опсег од 50 до 80 ms (Ludlow, Kent и Gray, 2019).

\section{Закдучок}

Локусот на F2 е највисок за палаталните консонанти и најнизок за лабијалните консонанти. Транзицијата на F2 е акустичен знак за местото на артикулација на консонантите. Вториот формант на вокалите во контекст на фрикативи е повисок од F2 на вокалите изговорени како изолирани гласови. Транзициите на формантите се акустични знаци зависни од контекстот и насоката на транзицијата зависи од соседните консонанти. 


\section{References}

Al-Manie, M.A., Alkanhal, M.I. and Al-Ghamdi, M.M. (2010). Arabic speech segmentation: Automatic versus manual method and zero crossing measurements. Indian Journal of Science and Technology, 3(12), pp. 11341138.

Baken, R.J. and Orlikoff, R.F. (2000). Clinical measurement of speech and voice. 2nd ed. San Diego: Singular Thomson Learning, pp. 273-274.

Blomgren, M. and Robb, M. (1998). How steady are vowel steady-states? Clinical Linguistics \& Phonetics, 12(5), pp. 405-415.

Boersma, P. and Weenink, D. Praat [Computer program]. Version 6.0.43. Retrieved 24.10.2018 from: http://www.fon.hum.uva.nl/praat/

Boersma, P. and Weenink, D. (2001). Praat, a system for doing phonetics by computer. Glot International, 5(9/10), pp. 341-347.

Бојковска, С., Минова-Ѓуркова, А., Пандев, Д. и Цветковски, Ж., (2008). Опита граматика на македонскиот јазик. Скопје: Просветно дело, стр. 102 - 103.

Goldstein, E.B. (2010). Sensation and perception. 8th ed. Belmont: Wadsworth, Cengage Learning, p. 315.

Gunasekar, C., Sabrigirinathan, C., Vinayagavel, K. and Ramkumar, K. (2017). The acoustic parameters for analyzing speech with complete dentures. International Journal of Dental Research, 5(2), pp. 115-120.

Kerdpol, K. (2012). Formant transitions as effective cues to differentiate the places of articulation of Ban Pa La-u Sgaw Karen Nasals. MANUSYA: Journal of Humanities Regular, 15(2), pp. 21-38.

Kishon-Rabin, 1., Dayan, M. and Michaeli, O. (2003). Effects of second-formant transition on the perception of Hebrew voiced stop consonants. Journal of Basic and Clinical Physiology and Pharmacology, 14(2), pp. 151-164.

Ladefoged, P. and Johnson, K. (2011). A course in phonetics. 6th ed. Boston: Cengage Learning, pp. 199, 204.

Ludlow, C.L., Kent, R.D. and Gray, L.C. (2019). Measuring voice, speech, and swallowing in the clinic and laboratory. San Diego: Plural Publishing, pp. 181, 188, 194.

Maltby, M.T. (2002). Principles of hearing aid audiology. 2nd ed. London: Whurr Publishers, p. 75.

Marchal, A. (2009). From speech physiology to linguistic phonetics. London: ISTE, p. 173.

Ogden, R. (2009). An introduction to English phonetics. Edinburgh: Edinburgh University Press, p. 17.

Proverbio, A.M., Massetti, G., Rizzi, E. and Zani, A. (2016). Skilled musicians are not subject to the McGurk effect. Scientific Reports, 6:30423.

Raina, D., Chakraborty, S. and Velankar, M.R. (2014). Automatic classification of instrumental music \& human voice using formant analysis. International 
Journal of Advanced Research in Computer Science \& Technology, 2(2), pp. 242-245.

Raphael, L.J., Borden, G.J. and Harris, K.S. (2011). Speech science primer: physiology, acoustics, and perception of speech. 6th ed. Baltimore: Lippincott Williams \& Wilkins, pp. 214-215.

Ристовска, Л., Јачова, 3., Спасов Љ. и Балова, Т. (2018). Акустични карактеристики на македонските вокали. Дефектолошка теорија и практика, 19(3 - 4), стр. 40 - 50.

Stevens, K.N. (2000). Acoustic phonetics. Cambridge: MIT Press, p. 377.

Story, B.H. and Bunton, K. (2010). Relation of vocal tract shape, formant transitions, and stop consonant identification. Journal of Speech, Language, and Hearing Research, 53, pp. 1514-1528.

Tatham, M. and Morton, K. (2006). Speech production and perception. Basingstoke: Palgrave Macmilan, p. 23.

Taylor, P. (2009). Text-to-speech synthesis. New York: Cambridge University Press, pp. 159.

Yadav, J. and Rao, K.S. (2013). Detection of vowel offset point from speech signal. IEEE Signal Processing Letters, 20(4), pp. 299-302. 
